\title{
LITERASI MATEMATIKA DALAM PROSES BELAJAR MATEMATIKA DI SEKOLAH MENENGAH ATAS
}

\author{
Sri Lindawati \\ SMA Negeri 4 Pekanbaru \\ Email : srilinda_w@yahoo.com
}

\begin{abstract}
Abstrak. Literasi Matematika adalah kemampuan seseorang untuk merumuskan, menggunakan dan menafsirkan matematika dalam berbagai konteks masalah kehidupan sehari-hari secara efisien. Kemampuan literasi matematika siswa tidak hanya memiliki keterampilan berhitung tetapi juga kemampuan berpikir logis dan kritis dalam pemecahan masalah. Berdasarkan hasil PISA 2015, kemampuan siswa Indonesia dalam matematika dan membaca masih rendah dibandingkan dengan negara lain. Untuk memecahkan masalah ini guru matematika harus mengetahui dan memahami, apa dan bagaimana literasi matematika dan dapat diterapkan dalam setiap pembelajaran sebagai upaya meningkatkan kemampuan literasi matematika. Jadi, dalam makalah ini dijelaskan studi literatur yang berkaitan dengan keaksaraan dalam belajar matematika di sekolah menengah atas.
\end{abstract}

Kata Kunci: Literasi matematika, Sekolah Menengah Atas, Proses belajar matematika.

\section{PENDAHULUAN}

Istilah Literasi Matematika dewasa ini menjadi topik hangat yang sering diperbincangkan dalam diskusi-diskusi guru dan para pakar matematika tidak hanya di Indonesia bahkan di seluruh dunia. Literasi matematika telah menjadi isu utama dalam kajian survei internasional PISA (Program for International Student Assessment). Survei ini diselenggarakan tiga-tahunan untuk menguji pencapaian akademis anak-anak sekolah yang berusia 15 tahun, dan penyelenggaraannya dilaksanakan oleh Organization for Economic CoOperation Development (OECD) yaitu suatu organisasi untuk kerjasama dan pengembangan ekonomi yang kantor pusatnya berkedudukan di Paris, Prancis. Tujuan dari penilaian ini adalah untuk mengukur prestasi siswa dalam literasi membaca, matematika, dan sains siswa sekolah di negara-negara peserta. Menurut OECD (2016: 5-9) dari 70 negara yang berpartisipasi dalam PISA 2015, Indonesia, bidang matematika peringkat 63 dan bidang membaca peringkat 64. Hal ini menunjukkan bahwa kemampuan siswa Indonesia dalam matematika dan membaca itu masih sangat rendah jika dibandingkan dengan negara-negara lain.

Soal-soal literasi pada studi PISA menuntut kemampuan penalaran dan pemecahan masalah yang menekankan pada berbagai masalah dan situasi dalam kehidupan seharihari. Kemampuan yang diujikan dalam PISA dikelompokkan dalam komponen proses yaitu kemampuan pemahaman dan pemecahan masalah (problem solving), kemampuan penalaran (reasoning), dan kemampuan komunikasi (communication).

Jika kita melihat hasil yang diperoleh dari kajian survei PISA tersebut, maka tentunya kita sebagai guru khususnya guru matematika merasa miris dengan keadaan ini. Apa yang salah dengan siswa-siswi kita dalam hal kemampuan literasi matematika? Bagaimana kita dapat mengambil peran dalam hal mencoba untuk memperbaiki hal ini? Memang untuk memperbaiki kondisi ini bukanlah hal yang mudah semudah membalikkan telapak tangan. Namun dengan menyadari hal ini setidaknya kita dapat melakukan hal yang dapat meningkatkan kemampuan literasi matematika bagi para siswa kita.

Menurut Rosalia (2015) kemampuan matematika seorang siswa tidak hanya sekedar memiliki kemampuan berhitung saja, tetapi juga kemampuan dalam berpikir logis dan kritis dalam pemecahan masalah. pemecahan masalah ini tidak semata-mata masalah yang berupa soal rutin akan tetapi lebih kepada permasalahan yang dihadapi sehari-hari. Kemampuan matematis yang demikian dikenal sebagai kemampuan literasi matematika. Artinya seseorang yang memahami matematika tidak hanya mampu berhitung, namun mampu memaknai dan menggunakan matematika dalam berbagi konteks permasalahan dalam kehidupan nyata. 
Peraturan Menteri Pendidikan Nasional Nomor 22 Tahun 2006 yang juga memuat standar isi mata pelajaran matematika telah mengakomodir dan selaras dengan pengembangan literasi matematika menyatakan tujuan pembelajaran matematika diantaranya adalah agar peserta didik memiliki kemampuan: menggunakan penalaran pada pola dan sifat, melakukan manipulasi matematika dalam membuat generalisasi, menyusun bukti, atau menjelaskan gagasan dan pernyataan matematika, mengkomunikasikan gagasan dengan simbol, tabel, diagram, atau media lain untuk memperjelas keadaan atau masalah, serta memiliki sikap menghargai kegunaan matematika dalam kehidupan, yaitu memiliki rasa ingin tahu, perhatian, dan minat dalam mempelajari matematika, serta sikap ulet dan percaya diri dalam pemecahan masalah. Demikian pula halnya tujuan yang diharapkan dalam pembelajaran matematika oleh National Council of Teachers of Mathematics (NCTM) (Wahyudin, 2008), yang menetapkan standar-standar kemampuan matematis seperti pemecahan masalah, penalaran dan pembuktian, komunikasi, koneksi, dan representasi, seharusnya dapat dimiliki oleh peserta didik.

Menurut Kohar (2014) sebagai salah satu langkah yang dilakukan oleh pemerintah Indonesia untuk meningkatkan kemampuan literasi ini melalui momen berlakunya kurikulum 2013, yaitu dengan menggunakan hasil studi PISA sebagai salah satu dasar perbaikan kurikulum pembelajaran. Kemendikbud juga menganjurkan perlu adanya perubahan orientasi kurikulum dengan mengutamakan aspek kemampuan esensial yang diperlukan semua warga negara di masa mendatang. Tentu saja hal ini sejalan dengan konsep penilaian pada PISA yang mengutamakan kemampuan literasi matematika sebagai kemampuan esensial yang dibutuhkan saat ini.

Konsep yang telah dilontarkan oleh pemerintah perlu dipahami secara mendalam oleh para guru matematika yang seyogyanya merupakan agen pembaharu dalam menyampaikan proses pembelajaran khususnya di sekolah menengah atas. Perlu pemahaman dan kemampuan guru dalam mengimplementasi kurikulum 2013 yang mengintegrasikan konten PISA ke dalam pembelajaran matematika. Selain itu guru juga perlu mendapatkan motivasi untuk mengubah paradigma konten matematika yang disampaikan di ruang kelas. Mengimplementasikan konsep literasi matematika dalam proses belajar matematika sehingga nantinya mampu melahirkan para siswa yang memiliki kemampuan literasi matematika. Untuk itu dalam tulisan ini yang merupakan studi literatur tentang apa dan bagaimana literasi matematika dan bagaimana penerapannya dalam pembelajaran di SMA. Sehingga tulisan ini nantinya dapat bermanfaat bagi para guru matematika dalam mengembangkan pembelajaran yang menerapkan konsep literasi dalam proses pembelajaran matematika.

\section{HASIL DAN PEMBAHASAN}

PISA dalam studinya menggunakan istilah 'literasi' untuk merujuk pada penilaian bukan hanya pada kompetensi pengetahuan, tetapi juga kemampuan mengaplikasikan pengetahuan tersebut. Secara formal, literasi matematika dalam kerangka PISA matematika 2015 didefinisikan sebagai berikut, "Mathematical literacy is an individual's capacity to formulate, employ, and interpret mathematics in a variety of contexts. It includes reasoning mathematically and using mathematical concepts, procedures, facts and tools to describe, explain and predict phenomena. It assists individuals to recognise the role that mathematics plays in the world and to make the well-founded judgments and decisions needed by constructive, engaged and reflective citizens." Dari definisi ini, setidaknya terdapat tiga hal penting yang menjadi inti dari konsep literasi matematika, yaitu:1) kemampuan merumuskan, menerapkan, dan menafsirkan matematika dalam berbagai konteks, 2) penalaran matematis dan penggunaan konsep, prosedur, fakta, dan alat matematika untuk mendeskripsikan, menjelaskan, dan memprediksi fenomena, dan 3) manfaat dari kemampuan literasi matematika yaitu dapat membantu seseorang dalam menerapkan matematika ke dalam dunia sehari-hari sebagai wujud dari keterlibatannya dalam kehidupan masyarakat yang konstruktif dan reflektif.

Beberapa pertanyaan muncul terkait literasi matematika yang dilakukan oleh PISA terhadap para siswa yang berusia 15 tahun. 
1. Proses apa yang sebaiknya dilakukan oleh siswa saat memecahkan masalah matematika kontekstual?

2. Kemampuan apa saja yang kita harapkan dari para siswa agar mereka dapat meningkatkan kemampuan literasi matematika?

3. Materi apa saja yang perlu dipelajari dan dikembangkan oleh para siswa di SMA?

4. Bagaimana penilaian dalam penerapan literasi matematika?

Beberapa pertanyaan ini dapat membuat para guru berpikir bagaimana menerapkan pembelajaran yang menekankan pada literasi matematika. Untuk itu kita perlu memahami tujuh kemampuan dasar yang harus dimiliki siswa menurut PISA(2013) sebagai berikut:

1. Komunikasi: kemampuan literasi matematika melibatkan kemampuan komunikasi. Para siswa merasakan adanya beberapa tantangan dan di rangsang untuk mengenali dan memahami suatu masalah maupun situasi. Membaca, memodelkan dan menafsirkan pernyataan, pertanyaan, tugas atau objek yang mungkin merupakan langkah penting dalam memahami, mengklarifikasi dan merumuskan suatu masalah dan kemudian menyelesaikan dan menyajikan hasil solusi yang diperoleh.

2. Mathematising: kemampuan matematika yang dapat melibatkan transformasi masalah yang didefinisikan secara nyata ke bentuk matematika (yang dapat mencakup penataan, pembuatan konsep, pembuatanasumsi, dan / atau perumusan model), atau menafsirkan atau mengevaluasi matematika hasil atau model matematis dalam kaitannya dengan masalah aslinya. Istilah mathematising digunakan untuk menggambarkan aktivitas pada konsep matematika yang terlibat.

3. Representasi: di dalam matematika sangat sering melibatkan representasiobjek dan situasi matematika. Ini bisa berarti memilih, menafsirkan, dan menggunakan berbagai representasi untuk menangkap suatu situasi, berinteraksi dengan suatu masalah, atau untuk mempresentasikan karya seseorang. Representasi yang dimaksud meliputi grafik, tabel, diagram, gambar, persamaan, formula, dan materi.

4. Penalaran dan argumentasi: kemampuan matematis yang disebut di sepanjang perbedaan tahapan dan kegiatan yang terkait dengan matematika disebut sebagai penalaran dan argumentasi. Kemampuan ini melibatkan proses pemikiran yang berakar logis yang mengeksplorasi dan menghubungkan elemen masalah sehingga membuat kesimpulan, memeriksa pembenaran yang diberikan, atau memberikan pembenaran terhadap pernyataan atau solusi terhadap masalah.

5. Merancang strategi untuk memecahkan masalah: Dalam membicarakan masalah matematika membutuhkan perencanaan strategi pemecahan masalah secara matematis. Ini melibatkan serangkaian proses yang membimbing seseorang untuk secara efektif mengenali, merumuskan dan memecahkan masalah. Ini merupakan keterampilan dalam memilih atau menyusun rencana atau strategi untuk menggunakan matematika dalam pemecahan masalah yang timbul dari suatu konteks.

6. Menggunakan bahasa dan operasi, simbol, formal dan teknis: matematika membutuhkan penggunaan bahasa dan operasi simbolis, formal dan teknis dalam memahami, menafsirkan, memanipulasi, dan menggunakan ungkapan simbolik dalam konteks matematis (termasuk ungkapan aritmetika dan operasi) yang diatur oleh konvensi matematika.

7. Menggunakan alat matematika: Kemampuan matematis terakhir yang mendasari matematis dalam praktiknya menggunakan alat matematika. Alat matematika mencakup alat fisik seperti alat ukur, serta kalkulator dan alat berbasis komputer yang ada menjadi lebih banyak tersedia. Kemampuan ini melibatkan mengetahui dan mampu membuat penggunaan berbagai alat yang bisa membantu aktivitas matematis, dan mengetahui keterbatasannya.

Dari beberapa paparan di atas setidaknya guru harus dapat menerapkan pembelajaran yang dapat menumbuhkan kembangkan kemampuan dasar matematika yang diharapkan mampu meningkatkan kemampuan siswa dalam 
literasi matematika. Rosalia (2015) menyatakan bahwa mengingat pentingnya kemampuan literasi matematika, maka diperlukan usaha dalam rangka mengembangkan kemampuan tersebut. Pembelajaran matematika hendaknya memberikan kesempatan atau pengalaman kepada siswa untuk menyelesaikan masalah dalam berbagai situasi. Melalui cara ini siswa akan mengaktifkan kemampuan literasinya sekaligus mengembangkannya. Selanjutnya seperti ungkapan Lakatos (Ernest, 1991), "mathematical activity is human activity", artinya dalam pembelajaran matematika harus memberikan kesempatan bagi para siswa untuk dapat melakukan aktivitas dari aktivitas manusia sehari-hari. Di dalam Kurikulum 2013, dengan berbagai macam model pembelajaran yang bersifat scientific dan konstruktivis, sebenarnya dapat terus menjadi acuan para guru matematika dalam mengembangkan pembelajaran di kelas. Pembelajaran selama ini di kelas matematika masih belum mampu mengembangkan kemampuan literasi matematika, Untuk itu, guru matematika mau tidak mau harus mengupayakan berbagai macam model dan strategi pembelajaran yang memfasilitasi siswa dalam pengalaman belajarnya. MIsalnya seperti model pembelajaran inkuiri, problem based learning, discovery learning dan lain sebagainya. Selanjutnya berbagai konteks permasalahan dalam kehidupan tersaji dalam penilaian oleh PISA (2013) dapat dilihat bentuk soal-soal yang ditampilkan sebagai berikut:

\section{Masalah Penjualan CD Musik}

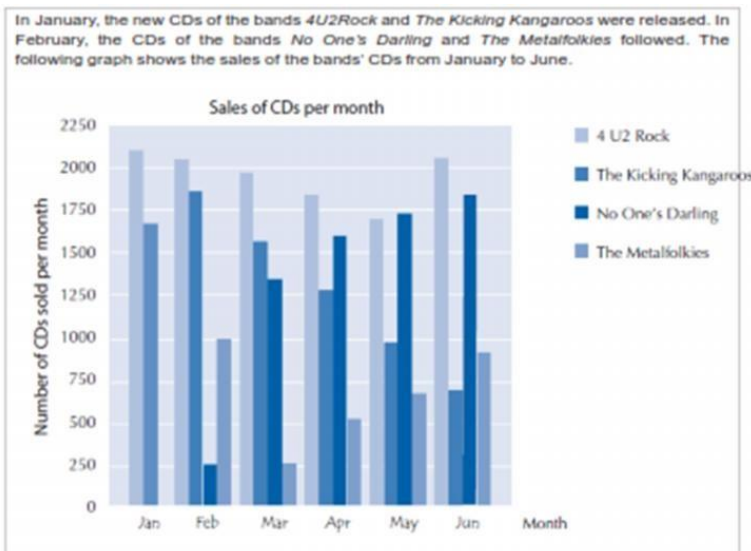

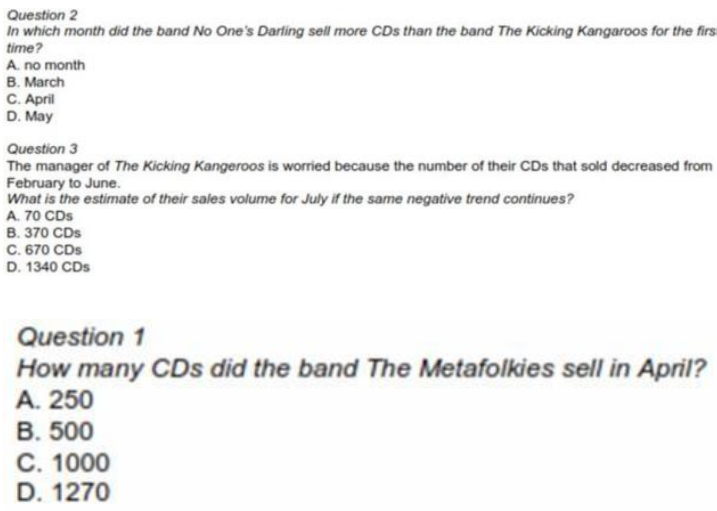

Gambar 1. Masalah Penjualan CD Masuk

Grafik yang digunakan dalam survei utama PISA 2012 ini meminta siswa untuk membaca, menafsirkan dan menggunakan data yang disajikan dalam bentuk grafik. Data yang disajikan berhubungan dengan informasi publik tentang penjualan musik, jenis yang mungkin ditemukan di koran, majalah musik atau online. Dua pertanyaan pertama adalah contoh penafsiran, penerapan dan evaluasi kategori hasil proses matematis, karena pertanyaan ini melibatkan interpretasi matematis informasi yang disajikan dalam bagan dalam kaitannya dengan fitur konteks yang ditampilkan sedangkan pertanyaan ketiga menggunakan fakta matematika, konsep, prosedur dan kategori penalaran karena fokusnya sedang menerapkan pengetahuan prosedural untuk memanipulasi representasi matematis agar bisa dibuat sebuah kesimpulan lebih lanjut

\section{Masalah Jejak Kaki}

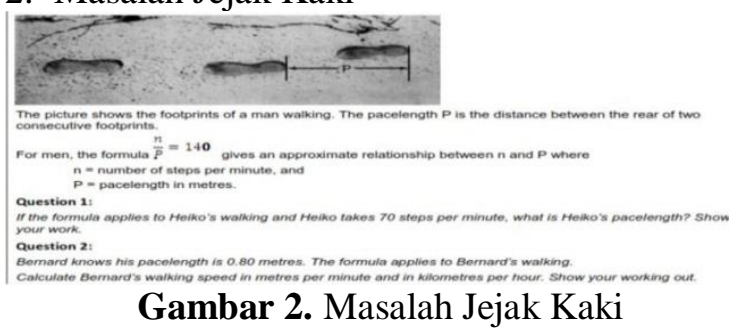

3. Masalah Gunung Fuji

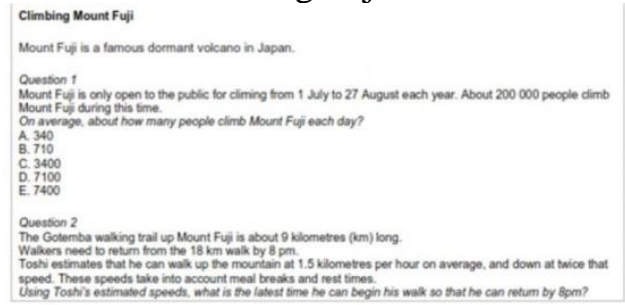

Gambar 3. Masalah Gunung Fuji 
Masalah Gunung Fuji digunakan dalam survei utama PISA 2012, di sini siswa diminta siswa untuk menghitung tanggal dan pengukuran dan membuat konversi. kecepatan sebagai konsep utamanya dan di sini siswa diharapkan mampu membuat model matematis yang bisa menjawab pertanyaan yang diajukan.

\section{Masalah Tukang Kayu}

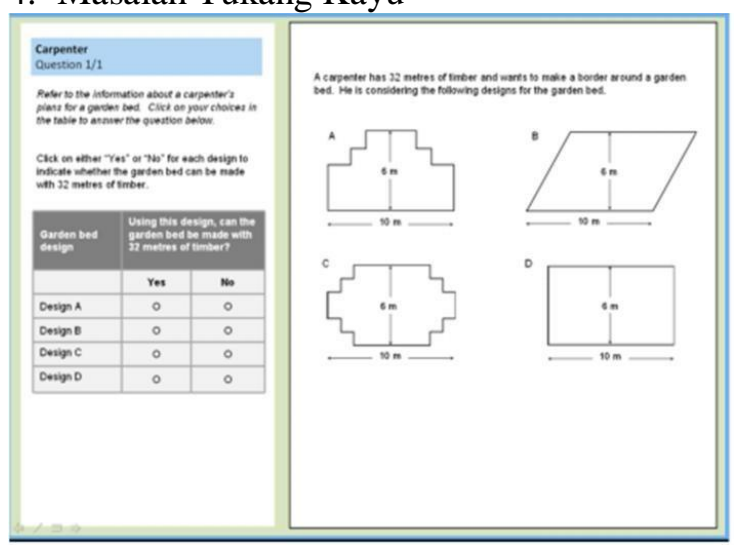

Gambar 4. Masalah Tukang Kayu

Masalah Tukang kayu disajikan di atas ini digunakan pada survey PISA tahun 2003. Bentuk pilihan respons merupakan pilihan ganda yang kompleks, di mana siswa harus memilih satu tanggapan dari pilihan yang terkait pada masing- masing sejumlah pernyataan atau pertanyaan. Dalam hal ini, siswa diharapkan mampu mengidentifikasi bahwa semua desain kecuali desain $\mathrm{B}$ dapat dibuat dengan jumlah yang ditentukan dari kayu yang ada.

Masalah ini adalah masalah bentuk yang diklasifikasikan berdasarkan konsep matematika, fakta, prosedur dan proses penalaran yang digunakan karena sebagian besar pekerjaan tukang kayu melibatkan penerapan pengetahuan prosedural untuk didefinisikan dengan baik sehingga berbagai unsur dan kendala dapat diperhatikan dalam memanfaatkan kayu yang ada.

Dari beberapa permasalahan yang ditampilkan, jelas bahwa masalah- masalah yang dimunculkan di dalam PISA merupakan masalah-masalah yang kontekstual dan berkaitan dengan kehidupan nyata sehari-hari. Pada materi yang dimunculkan memang dapat mengaitkannya dengan masalah-masalah dalam kehidupan sehari-hari. Hal ini dapat membuka wawasan para guru karena selama ini matematika dianggap ilmu yang kaku dan kering.

\section{SIMPULAN}

Kemampuan Literasi Matematika merupakan merupakan kemampuan seseorang untuk merumuskan, mengunakan dan menafsirkan matematika dalam berbagai konteks masalah kehidupan sehari-hari secara efisien. Kemampuan literasi matematika seorang siswa tidak hanya sekedar memiliki kemampuan berhitung saja, tetapi juga kemampuan dalam berpikir logis dan kritis dalam pemecahan masalah. Kemampuan literasi matematika ini adalah kemampuan yang penting dikembangkan bagi para siswa sehingga diperlukan usaha dalam rangka mengembangkan kemampuan tersebut. Untuk mengembangkan kemampuan literasi matematika, guru harus dapat menerapkan pembelajaran yang bersifat kontekstual dan melibatkan siswa dalam aktivitas yang membuat para siswa dapat mengaitkan materi yang diperoleh pada konteks kehidupan nyata ataupun memberikan kesempatan atau pengalaman kepada siswa untuk menyelesaikan masalah dalam berbagai situasi, sehingga dapat menumbuhkan kembangkan kemampuan dasar matematika yang selanjutnya nanti diharapkan mampu meningkatkan kemampuan siswa dalam literasi matematika.

\section{DAFTAR PUSTAKA}

Ernest, P. (1991). The Philosophy of Mathematics Education. London: The Faler Press.

Fathani, A.H. (2016). Pengembangan Literasi Matematika Sekolah dalam Perspektif Multiple Inteligent. Jurnal Edusains Vol. 4 No.2.

Kohar, Wachidul. A. (2014). Pengembangan Soal Berbasis Literasi Matematika dengan Menggunakan Kerangka PISA 2012. Prosiding Konferensi Nasional Matematika XVII ITS Surabaya.

OECD. (2013): Draft PISA 2015 Mathematics Framework. OECD publishing,http://www.oecd.org/pisa/pisapr oducts diakses tanggal 29 Januari 2018 pukul 14.20. 
PRINSIP Pendidikan Matematika

Volume 1, Nomor 1, November 2018

OECD. (2016). PISA 2015: PISA Result in Focus. http://www.oecd.org/pisa diakses tanggal 22 Januari 2018 pukul 11.15.

Peraturan Menteri Pendidikan Nasional Nomor 22 Tahun 2006 tentang Standar Isi untuk Satuan Pendidikan Dasar dan Menengah.
Rosalia Hera Novita Sari. (2015). Literasi matematika: Apa, Mengapa, dan Bagaimana. Seminar Nasional Matematika dan Pendidikan Matematika. (Yogyakarta: Universitas Negeri Yogyakarta). http://seminar.uny.ac.id diakses tanggal 28 Januari 2018 Pukul 13.55 .

Wahyudin. (2008). Pembelajaran dan Modelmodel Pembelajaran. Bandung: JICA 